Post-print

\title{
Plasmonic photothermal cancer therapy with gold nanorods/reduced graphene oxide core/shell nanocomposites
}

Authors: Kostiantyn Turcheniuk ${ }^{\mathrm{a}}$, Tetiana Dumych ${ }^{\mathrm{b}}$, Rostyslav Bilyy ${ }^{\mathrm{bc}}$, Volodymyr Turcheniuk $^{\text {ad }}$, Julie Bouckaert ${ }^{\mathrm{b}}$, Volodymyr Vovk $^{\mathrm{c}}$, Valentyna Chopyak ${ }^{\mathrm{c}}$, Vladimir Zaitsev ${ }^{\mathrm{de}}$, Pascal Mariot ${ }^{\mathrm{f}}$, Natasha Prevarskaya ${ }^{\mathrm{f}}$, Rabah Boukherroub ${ }^{\mathrm{a}}$ and Sabine Szunerits*a

anstitut d'Electronique, de Microélectronique et de Nanotechnologie (IEMN), UMR CNRS8520, Université Lille1, Avenue Poincaré-BP 60069, 59652 Villeneuve d'Ascq, France. E-mail: sabine.szunerits@univ-lille1.fr

${ }^{\text {b} U n i t e ́ ~ d e ~ G l y c o b i o l o g i e ~ S t r u c t u r a l e ~ e t ~ F o n c t i o n n e l l e ~(U G S F), ~ U n i v e r s i t e ́ ~ L i l l e ~ 1, ~ C N R S ~ U M R ~}$ 8576, 59655 Villeneuve d'Ascq, France

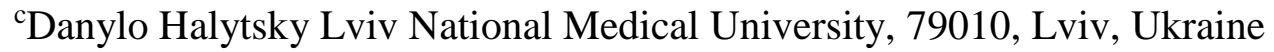

${ }^{\mathrm{d}}$ Taras Shevchenko University, 60 Vladimirskaya str., Kiev, Ukraine

${ }^{\text {e}}$ Chemistry Department, Pontifical Catholic University of Rio de Janeiro, Rua Marques de Sao Vicente, 225-Gavea, Rio de Janeiro, 22451-900, Brazil

fLaboratoire de Physiologie Cellulaire INSERM U1003, Equipe Labellisée par la Ligue Nationale, Contre le Cancer et LABEX (Laboratoire d'excellence), Université Lille1, 59655 Villeneuve d'Ascq, France

First published: $17 / 12 / 2015$

DOI: $10.1039 / \mathrm{C} 5 \mathrm{RA} 24662 \mathrm{H}$

\begin{abstract}
.
Gold nanorods (Au NRs) are known for their efficient conversion of photon energy into heat, resulting in hyperthermia and suppression of tumor growth in vitro and in vivo. Au NRs are thus of great promise for photothermal therapy (PTT) of different cancers. From the point of cancer therapy, low laser powers are essential $\left(\leq 1 \mathrm{~W} \mathrm{~cm}^{-2}\right)$ to ensure minimal side effects such as skin burning. Herein, we investigate the potential of polyethylene glycol functionalized reduced graphene oxide (rGO-PEG) enrobed Au NRs for the photothermal destruction of human glioblastoma astrocytoma (U87MG) cells in mice. We show that Au NRs@rGO-PEG are ideal multifunctional theranostic nanostructures that can exert efficient photothermal destruction of tumors in mice upon low doses of NIR light excitation and can act as fluorescent cellular markers due to the presence of a NIR dye integrated onto the rGO shell. Due to the specific interaction between Tat protein modified Au NRs@rGO-PEG nanostructures with the human glioblastoma astrocytoma (U87MG) cells, selective targeting of the tumor is achieved. In vivo experiments in mice show that upon irradiation of the tumor implanted in mice at 800

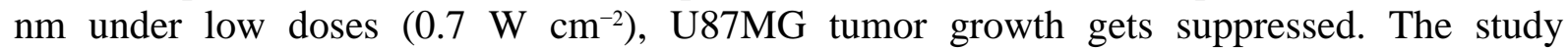
demonstrates that the novel nanomaterials allow for an efficient destruction of solid tumors and might thus serve as an excellent multi-functional theranostic agent in photothermal therapeutic applications.
\end{abstract}




\section{Introduction}

While surgery and chemotherapy remain the major therapeutic approaches for the treatment of a wide range of cancers, nanoparticle-based anticancer therapies have been extensively developed over the last few years as an effective treatment of advanced-stage cancers. $\frac{1-4}{}$ One major drawback using drug-based therapies particularly when administered orally or intravenously is that the compound does not localize to the target site. This nonspecific delivery of chemotherapeutic agents leads to systematic side effects of normal tissues and limits efficacy in killing the tumor. Targeted nanostructure-based cancer therapy has been developed with the objective to achieve higher levels of precision through specific accumulation of the therapeutic nanostructure in the tumor rather than in the normal tissue. Among the nanoparticles currently considered for cancer, gold nanostructures are particularly well-suited. $\stackrel{5-11}{ }$ The localized surface plasmon resonance (LSPR) of gold nanoparticles $\frac{12}{2}$ endows them with the capability to strongly absorb light at a specific wavelength, which can be controlled and tuned through synthetic means. Photo-excitation of gold nanostructures at their LSPR band can efficiently convert photon energy into heat and can be used for the photothermal ablation of cancer cells. Unlike spherical nanoparticles, which absorb light in the visible region, $\frac{13-17}{18}$ gold nanorods (Au NRs) shift the excitation wavelength to the near-infrared region (NIR). $\stackrel{18}{ }$ The flexibility in tuning the longitudinal plasmon band to the NIR makes them attractive for in vivo biomedical detection and therapy, as light in the NIR region can deeply penetrate into tissue without significant absorption and heat generation. Au NRs are thus of great promise in photothermal therapy (PTT) of cancers and other diseases. $\frac{14,19-23}{}$ From the point of cancer therapy, low laser powers are essential $\left(\leq 1 \mathrm{~W} \mathrm{~cm}^{-2}\right)$ to ensure minimal side effects such as skin burning. In many reported studies, the intensity of the laser exceeded $1 \mathrm{~W} \mathrm{~cm}^{-2}, \stackrel{8,24-26}{ }$ and it is only more recently that more attention has been paid to this parameter. $\frac{7,27-29}{3 i m o d a l ~ P T T ~ a n d ~ p h o t o d y n a m i c ~ c a n c e r ~}$ treatments are one way to overcome this limitation. ${ }^{7}$ The development of novel gold nanostructures and hybrids with a more efficient light-to-heat conversion is the other option. ${ }^{27,28,30}$ The wrapping and embedding of gold nanostructures within graphene oxide (GO) and reduced graphene oxide (rGO) could be a way into this direction. $\frac{31-33}{3}$ Kohane and coworkers showed that rGO coated gold nanoparticles kill cells more rapidly under $808 \mathrm{~nm}$ irradiation with a laser intensity of $3 \mathrm{~W} \mathrm{~cm}^{-2}$, than did uncoated particles. $\frac{31}{\text { The photothermal }}$ therapeutic response of cancer cells to aptamer-modified gold nanoparticles embedded on GO showed to facilitate targeted photothermal treatment in the NIR at $2 \mathrm{~W} \mathrm{~cm}{ }^{-2} . \underline{32} \mathrm{We}$ have recently demonstrated the interest of rGO wrapped Au NRs for the photothermal ablation of bacteria. $\frac{33}{3}$ In this work, we report that Au NRs coated with pegylated rGO (Au NRs@ rGO-PEG) are ideal multi-functional theranostic nanostructures that can exert efficient photothermal destruction of tumors in mice upon NIR light excitation and can act as fluorescent cellular markers. Due to the specific interaction between Au NRs@rGO-PEG nanostructures modified with Tat protein vectors towards human glioblastoma astrocytoma (U87MG) cells, selective targeting of the tumor is achieved. We believe that such nanomaterials can open up new perspectives in cancer treatments due to the highly nontoxic and local approach.

\section{Experimental section}

\section{Materials}

All chemicals were of reagent grade or higher and were used as received. Graphite flakes, chloroacetic acid, sodium hydroxide, poly(ethyleneglycol)-bis(3-aminopropyl) $\left(\mathrm{NH}_{2} \mathrm{PEGNH}_{2}\right.$, $\left.\mathrm{M}_{\mathrm{w}}=1.5 \mathrm{kDa}\right), \mathrm{N}$-(3-dimethylaminopropyl)- $\mathrm{N}^{\prime}$-ethylcarbodiimide (98\%, EDC), cetyltrimethylammonium bromide $(\mathrm{CTAB})$, tetrachloroauric acid trihydrate $\left(\mathrm{HAuCl}_{4} \cdot 3 \mathrm{H}_{2} \mathrm{O}\right)$, silver nitrate $\left(\mathrm{AgNO}_{3}\right)$, ascorbic acid, sodium borohydride $\left(\mathrm{NaBH}_{4}\right)$, paraformaldehyde, hydrochloric acid, fluorescein-isothiocyanate (FITC), Fluoroshield ${ }^{\mathrm{TM}}$ with 1,4- 
diazobicyclo[2.2.2] octane and HIV-1 Tat protein were purchased from Sigma and used as received. U-87MG human glioblastoma astrocytoma was acquired from Sigma-Aldrich. Cy7NHS ester was obtained from Lumiprobe. Sterile PBS solution, Dulbecco's Modified Eagle Medium (DMEM), Fetal Bovine Serum (FBS) and antibiotics (penicillin/streptomycin) were obtained from Gibco by Life Technologies. CellMask ${ }^{\mathrm{TM}}$ Deep Red plasma membrane stain (C10046) was acquired from Life technologies. Hoechst 33342 trihydrochloride trihydrate was obtained from Invitrogen. Matrigel ${ }^{\mathrm{TM}}$ Matrix Growth Factor Complete medium from BD Biosciences (USA), MTS tetrazolium dye was acquired from Promega (France).

\section{Synthesis of pegylated rGO-wrapped gold nanorods (Au NRs@ rGO-PEG)}

Carboxylated rGO (rGO-COOH) was obtained from GO as described in (ref. 33 and 34). In short, sodium hydroxide $(\mathrm{NaOH}, 1.4 \mathrm{~g})$ and chloroacetic acid $\left(\mathrm{Cl}-\mathrm{CH}_{2}-\mathrm{COOH}, 1 \mathrm{~g}\right)$ were added to $50 \mathrm{~mL}$ of $\mathrm{GO}(20 \mathrm{mg})$ aqueous solution and sonicated at $35 \mathrm{kHz}$ for $2 \mathrm{~h}$ at $80{ }^{\circ} \mathrm{C}$ to convert hydroxyl groups present on $\mathrm{GO}$ to $\mathrm{COOH}$ via conjugation of acetic acid moieties and to partially reduce GO into $\mathrm{rGO}$. The resulting $\mathrm{rGO}-\mathrm{COOH}$ solution was quenched with $\mathrm{HCl}$ (20\%), washed (four times) with distilled water until neutral $\mathrm{pH}$ and purified by repeated rinsing/centrifugation (4000 rpm, $20 \mathrm{~min}$ ) cycles.

$\mathrm{Au}$ NRs were synthesized through a seed-mediated, surfactant-assisted procedure. $\frac{33}{}$ Seed solutions were prepared by mixing $\mathrm{HAuCl}_{4}(10 \mathrm{mM}, 125 \mu \mathrm{L})$ with an aqueous solution of CTAB $(0.1 \mathrm{M}, 10 \mathrm{~mL})$. To this was added ice-cold $\mathrm{NaBH}_{4}(0.01 \mathrm{M})$ and the solution stirred for $5 \mathrm{~min}$. The resulting seed solution became brownish yellow, and aged for $5 \mathrm{~min}$ at room temperature before use. For the growth solution, a total $85 \mu \mathrm{L}$ of $\mathrm{AgNO}_{3}(10 \mathrm{mM})$ and $500 \mu \mathrm{L}$ of $\mathrm{HAuCl}_{4}(10 \mathrm{mM})$ were mixed with $5 \mathrm{~mL}$ of water and $5 \mathrm{~mL}$ of CTAB $(0.2 \mathrm{mM})$ solution and acidified to $\mathrm{pH} 3-4$ with $\mathrm{HCl}(1 \%)$. Ascorbic acid $(0.1 \mathrm{M}, 60 \mu \mathrm{L})$ and $48 \mu \mathrm{L}$ of seed solution were added and the mixture left at $25{ }^{\circ} \mathrm{C}$ without stirring overnight. Excess of CTAB was discarded from the final product by centrifugation at $10000 \mathrm{rpm}$ for $30 \mathrm{~min}$. The precipitate was re-dispersed in $10 \mathrm{~mL}$ of Milli-Q water giving rise to Au NRs of a concentration of $40 \mu \mathrm{g} \mathrm{mL}^{-1}$, as determined by ICP-MS.

rGO-COOH $(500 \mu \mathrm{g})$ was added to $20 \mathrm{~mL}$ of Au NRs in Milli-Q water $\left(40 \mu \mathrm{g} \mathrm{mL}^{-1}\right)$ and mildly stirred for $96 \mathrm{~h}$ at $25^{\circ} \mathrm{C}$ to enable electrostatic interaction of the positively charged Au NRs with the negatively charged rGO-COOH matrix to give $\mathrm{Au}$ NRs@ $\mathrm{rGO}-\mathrm{COOH}$. This nanostructure was covalently modified with $10 \mathrm{mg}$ of $\mathrm{NH}_{2} \mathrm{PEGNH}_{2}\left(\mathrm{M}_{\mathrm{W}}=1.5 \mathrm{kDa}\right)$ by means of EDC $\left(100 \mu \mathrm{L}, 1 \mathrm{mg} \mathrm{mL}^{-1}\right)$ chemistry under sonication $\left(2 \mathrm{~h}, 35 \mathrm{kHz}, 40{ }^{\circ} \mathrm{C}\right)$ followed by dialysis $(3 \times 2000 \mathrm{~mL}$ Milli-Q water), filtration through $0.2 \mu \mathrm{m}$ filter with hydrophilic membrane and ultrafiltration (50 kDa cut-off ultracentrifuge Amicon ${ }^{\mathrm{TM}}$ filter membrane).

\section{Conjugation of Au NRs@ rGO-PEG with Cy7 or FITC and Tat protein vector}

To a solution of Au NRs@ rGO-PEG $\left(1 \mathrm{~mL}, 100 \mu \mathrm{g} \mathrm{mL} \mathrm{m}^{-1}\right)$ in Milli-Q water Cy7-NHS $(10 \mu \mathrm{g}$ $\left.\mathrm{mL}^{-1}\right)$ or FITC $\left(10 \mu \mathrm{g} \mathrm{mL}^{-1}\right)$ in DMSO was added and the solution stirred at room temperature for $48 \mathrm{~h}$. The nanostructures were filtered using a $35 \mathrm{kDa}$ cut-off ultracentrifuge Amicon ${ }^{\mathrm{TM}}$ filter membrane and re-dispersed in sterile PBS.

To a solution of Cy7 or FITC loaded Au NRs@rGO-PEG $\left(1 \mathrm{~mL}, 100 \mu \mathrm{g} \mathrm{mL} \mathrm{L}^{-1}\right)$ was added HIV1 Tat protein $\left(30 \mu \mathrm{L}, 1 \mathrm{mg} \mathrm{mL}^{-1}\right)$ and the mixture left stirring at room temperature for $24 \mathrm{~h} \mathrm{in}$ the presence of EDC $\left(20 \mu \mathrm{L}, 1 \mathrm{mg} \mathrm{mL}^{-1}\right)$. The formed nanostructures were filtered using 35 $\mathrm{kDa}$ cut-off ultracentrifuge Amicon ${ }^{\mathrm{TM}}$ filter membrane and re-dispersed in sterile PBS.

\section{Characterization}

3

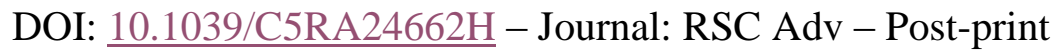


UV/Vis absorption spectra were recorded using a Perkin-Elmer Lambda UV/Vis 950 spectrophotometer in quartz cuvettes with an optical path of $10 \mathrm{~mm}$. The wavelength range was 200-1100 nm.

X-ray photoelectron spectroscopy (XPS) experiments were performed in a PHl 5000 VersaProbe - Scanning ESCA Microprobe (ULVAC-PHI, Japan/USA) instrument at a base pressure below $5 \times 10^{-9}$ mbar. Monochromatic AlK $\alpha$ radiation was used and the X-ray beam, focused to a diameter of $100 \mu \mathrm{m}$, was scanned on a $250 \times 250 \mu \mathrm{m}$ surface, at an operating power of $25 \mathrm{~W}(15 \mathrm{kV})$. Photoelectron survey spectra were acquired using a hemispherical analyzer at pass energy of $117.4 \mathrm{eV}$ with $0.4 \mathrm{eV}$ energy step. Core-level spectra were acquired at pass energy of $23.5 \mathrm{eV}$ with $0.1 \mathrm{eV}$ energy step. All spectra were acquired at $90^{\circ}$ between X-ray source and analyzer and with the use of low energy electrons and low energy argon ions for charge neutralization. After subtraction of the Shirley-type background, the core-level spectra were decomposed into their components with mixed Gaussian-Lorentzian (30:70) shape lines using the CasaXPS software. Quantification calculations were performed using sensitivity factors supplied by PHI. The sample was prepared by casting a concentrated aqueous solution of the material onto a silicon substrate followed by drying at $100{ }^{\circ} \mathrm{C}$ for $1 \mathrm{~h}$.

Transmission electron microscopy measurements were performed with a JOEL JEM 1011 microscope operating at an accelerating voltage of $100 \mathrm{kV}$.

SEM images were obtained using an electron microscope ULTRA 55 (Zeiss, France) equipped with a thermal field emission emitter and three different detectors (BSE detector with filter grid, high efficiency In-lens SE detector and Everhart-Thornley secondary electron detector). The sample was prepared by casting a concentrated aqueous solution of the material onto a silicon substrate followed by drying at $100{ }^{\circ} \mathrm{C}$ for $1 \mathrm{~h}$.

Zeta-potential measurements were performed by Zeta-sizer Nano-ZS (Malvern Instruments Inc. Worcestershire, UK). Nanomaterials were diluted to $10 \mu \mathrm{g} \mathrm{mL} \mathrm{L}^{-1}$ and measured in Milli-Q water at $\mathrm{pH}$ 7.0.

\section{Measurements of the photothermal effect}

All irradiations were performed in standard 96-well plates. The temperature changes were captured by an Infrared Camera (Thermovision A40) and treated using ThermaCam Researcher Pro 2.9 software. A $808 \mathrm{~nm}$-CW LASER (Gbox model, Fournier Medical Solution) was used for the photothermal experiments. This laser was injected into a $400 \mu \mathrm{m}$-core fiber which output was placed around $6 \mathrm{~cm}$ away from the bottom of the wells. This output was not collimated and the resulting beam divergence allowed us to illuminate uniformly up to 4 wells. This LASER also comprises a red pointing LASER with a power of less than $5 \mathrm{~mW}$ which allows the fine positioning of the fiber without interfering in the measurements.

\section{Cell culture and cellular uptake of Au NRs@rGO-PEG-FITC and Au NRs@rGO-PEG- Tat/FITC}

U87MG (human glioblastoma astrocytoma) cells were cultured in DMEM supplemented with fetal bovine serum FBS (10\% (v/v)) and antibiotics ((penicillin/streptomycin) 1\% (v/v)) at 37 ${ }^{\circ} \mathrm{C}$ in a $5 \% \mathrm{CO}_{2}$ atmosphere.

The U87MG cells $\left(5 \times 10^{4}\right.$ cells per well) were seeded on glass cover slips in 24-well culture plates and infected with Au NRs@rGO-PEG-FITC and Au NRs@rGO-PEG-Tat/FIT at $50 \mu \mathrm{g}$ $\mathrm{mL}^{-1}$ for 1,4 and $24 \mathrm{~h}$ at $37^{\circ} \mathrm{C}$. Cells were washed twice with PBS, and treated using next protocol: staining with $0.05 \times$ CellMask $\left(10\right.$ minutes, dark, $\left.20{ }^{\circ} \mathrm{C}\right)$, PBS $\times 2$, fixing in paraformaldehyde $\left(4 \%\right.$ in PBS, dark, $20^{\circ} \mathrm{C}$ ), PBS $\times 3$, staining with $2 \mu \mathrm{g} \mathrm{mL}{ }^{-1}$ Hoechst 33342 (15 min dark, $20{ }^{\circ} \mathrm{C}$ ), PBS $\times 2$, prior mounting on microscopic slides staining by means of Fluoroshield ${ }^{\mathrm{TM}}$ with 1,4-diazobicyclo[2.2.2] octane. Experiments were carried out with a Leica AF600 LX microscope (Leica Microsystems GmbH) equipped with a HCX PL APO CS

4

DOI: 10.1039/C5RA24662H - Journal: RSC Adv - Post-print 
100×/1.40 DIC (Oil) objective, an Andor iXon DU-885 EM-CCD camera (Andor Technology Ltd) and appropriate filter cubes. The excitation/emission wavelengths (nm) were 350/460 for Hoechst 33342, 492/534 for FITC, 575/632 for CellMask.

\section{Cellular toxicity of Au NRs@rGO-PEG}

To examine the biological effects of Au NRs@rGO-PEG on U87MG cells in terms of cell viability, colorimetric MTS [3-(4,5-dimethylthiazol-2-yl)-5-(3-carboxymethoxyphenyl)-2-(4sulfophenyl)-2H-tetrazolium] metabolic activity assays were performed using a PHERAstar FS by BMG LABTECH. In brief, U87MG cells were seeded in 96-wells plate (100 $\mu \mathrm{L}, \mathrm{DMEM})$ at a density 15000 cells per well. After $6 \mathrm{~h}$, the medium was replaced with fresh DMEM containing Au NRs@ rGO-PEG (1-200 $\left.\mathrm{g} \mathrm{mL}^{-1}\right)$ and incubated for $48 \mathrm{~h}$. The old medium was aspirated and fresh DMEM $(100 \mu \mathrm{L})$ and MTS tetrazolium dye $(10 \mu \mathrm{L}$, Promega $)$ was added. After $3 \mathrm{~h}$ the optical density of each well at $490 \mathrm{~nm}$ was recorded using a microplate reader. Each sample was measured in triplicate and Au NRs@ rGO-PEG and DMEM only taken as false positive controls.

\section{Photothermal in vitro experiment}

In vitro photothermal ablation tests on U87MG cells were performed in standard 96-well plates with a continuous wave laser (Gbox model, Fournier Medical Solution, France) with a wavelength at $808 \mathrm{~nm}$ and power density of $0.5-1.0 \mathrm{~W} \mathrm{~cm}^{-1}$ for up to $10 \mathrm{~min}$ in the presence of rGO-PEG, Au NRs and Au NRs@ rGO-PEG (5-40 $\left.\mu \mathrm{g} \mathrm{mL}^{-1}\right)$. Prior to irradiation, U87MG cells were incubated with the respective nanomaterial for $4 \mathrm{~h}$ followed by washing and postincubation for $48 \mathrm{~h}$. To examine toxic effect MTS test was performed.

\section{In vivo photothermal therapy and histology}

Studies involving animals, including housing and care, method of euthanasia, and experimental protocols, were conducted in accordance with the local animal ethical committee in the animal house (C59-00913; protocol CEEA 202012) of the University of Sciences and Technologies of Lille, under the supervision of Dr P. Mariot (59-009243).

Six-week old male Swiss nude mice (Charles River, France) were used for this investigation. The mice were housed in cages covered with air filters in a temperature-controlled room with a $12 \mathrm{~h}$ light/12 $\mathrm{h}$ dark schedule and kept on a standard diet with drinking water available ad libitum. All animal experiments were performed in accord with institutional ethnical guidelines. To evaluate the in vivo PTT efficiency of Au NRs@rGO-PEG-Tat/Cy7, tumor-bearing mice (subcutaneous U87MG xenografts) were prepared by inoculating a suspension of $5 \times 10^{6}$ U87MG cells per mouse (in the flank) in $50 \%$ (v/v) Matrigel. $\frac{32}{2}$ Tumor growth was monitored with caliper every two days by measuring its dimensions and calculating the volume. When the tumor grew to about $500 \mathrm{~mm}^{3}$ in volume, Au NRs@rGO-PEG-Tat/Cy7 (150 $\mu \mathrm{L}$ for $1 \mathrm{mg} \mathrm{mL}^{-1}$ per mouse) was injected intravenously. To assure significant statistical data, 3 animals were used in each group for monitoring tumor growth. After $20 \mathrm{~h}$ post-injection of the nanostructures, the tumor tissue was irradiated using a portable continuous wave laser (Gbox model, Fournier Medical Solution, France) at $808 \mathrm{~nm}$ and power density of $0.5-2.0 \mathrm{~W} \mathrm{~cm}^{-1}$ for up to $5 \mathrm{~min}, 2$ times, with 2 min interval. The surface temperature of the irradiated areas of skin was controlled by Infrared Camera (Thermovision A40). $24 \mathrm{~h}$ after irradiation some animals were sacrificed. Tumor progression in treated and untreated group was evaluated by measuring the tumor volume for 15 days.

In vivo tracking of Au NRs@rGO-PEG-Tat/Cy7 was performed with a Bruker Xtreme in vivo machine supplied with interline front-illuminated (FI) 16 MP CCD detector, $400 \mathrm{~W}$ Xenon Fluorescence illuminator (excitation wavelength range: 410-760 nm, emission filter wavelength range: $535-830 \mathrm{~nm}$ ) and module for animal warming air $20-40{ }^{\circ} \mathrm{C}$. The data was 
analyzed by high-performance Bruker Molecular Imaging (MI) software. The data represents mirror images of the mice.

For histological analysis, mice were sacrificed with cervical dislocation under anesthesia and tissues (heart, liver, kidneys, lung, lymph node, tumor), excised from the mice at day 1 post injection, were fixed with $4 \%$ neutral buffered formalin solution and embedded in paraffin according to the standard laboratory protocol. The sliced tissues were stained with haematoxylin and eosin (H\&E), and images were taken using an optical microscope (Zeiss AxioImager A1) using 10×, 40× and $100 \times$ objectives with normal (halogen) light and using color filter with transmission of 620-650 nm to visualize Au NRs@ rGO-PEG-Tat/Cy7.

\section{Results and discussion}

\section{Synthesis of gold nanorods coated with pegylated reduced graphene oxide (Au NRs@rGO-PEG)}

Fig. 1 shows schematically the preparation strategy used for wrapping Au NRs with rGO$\mathrm{COOH}$ and the integration of a NIR fluorescent marker together with the tumor targeting Tat vector. CTAB stabilized Au NRs with longitudinal surface plasmon centered at $\sim 800 \mathrm{~nm}$ were synthesized as described in our previous work. $\underline{\underline{33}}$ As the surface charge of CTAB-stabilized Au NRs is strongly positive with a zeta potential of $+40 \pm 2 \mathrm{mV}$, strong electrostatic interaction with negatively charged rGO-COOH $(\zeta=-45 \pm 2 \mathrm{mV})$ occurs (Table 1). Well defined Au NRsrGO-COOH were generated, comparable to those reported by Kohane and co-workers. $\frac{31}{A}$ representative SEM image shows the successful formation of a $\mathrm{rGO}-\mathrm{COOH}$ layer around the Au NRs (Fig. 1B). The size of rGO-COOH before integration was spherical with a diameter of

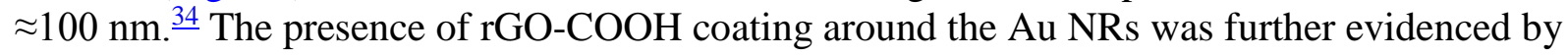
UV/Vis absorption spectra (Fig. 1C). Compared to GO, showing an optical absorption peak at $230 \mathrm{~nm}$, the Au NRs@rGO-COOH nanostructures exhibit a red shifted band at $269 \mathrm{~nm}$, indicating the recovery of the electronic transition state $\left(\pi-\pi^{*}\right)$ in rGO-COOH. The increase in the NIR absorption tail intensity is a further indication of the presence of $\mathrm{rGO}-\mathrm{COOH}$. The average aspect ratio (length/diameter) of the Au NRs was $3.8 \pm 0.3$ (Fig. 1B) resulting in a longitudinal LSPR maxima at $\approx 807 \mathrm{~nm}$ (Fig. 1C). The presence of an additional transversal oscillation band at $511 \mathrm{~nm}$ confirmed the formation of elongated Au NRs. In the case of Au NRs@rGO-COOH the longitudinal band shifted to $814 \mathrm{~nm}$, while the transversal band remained at $\approx 511 \mathrm{~nm}$ (Fig. $1 \mathrm{C})$.
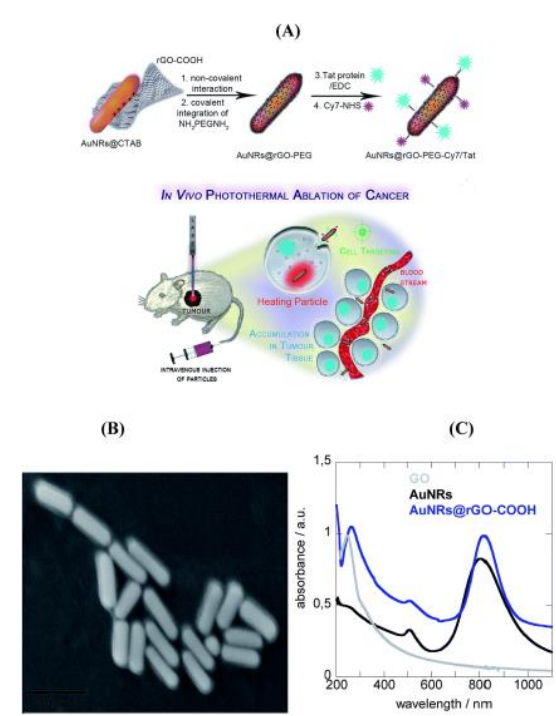

Fig. 1

Synthesis of Au NRs@rGO-PEG-Tat/Cy7 for hyperthermic treatment of tumors. (A) Illustration of the preparation of pegylated fluorescently labeled, 
Tat-protein modified Au NRs@rGO-PEG-Tat/Cy7; (B) SEM image of Au NRs@rGO-COOH; (C) UV-Vis absorption spectra of GO (grey), Au NRs (black) and Au NRs@rGO-COOH (blue).

Table 1 Zeta-potential of different nanostructures investigated in this work

\begin{tabular}{|c|c|c|c|c|c|c|}
\hline & $\begin{array}{l}\mathrm{Au} \\
\mathrm{NRs}\end{array}$ & $\begin{array}{l}\text { rGO- } \\
\mathrm{COOH}\end{array}$ & \begin{tabular}{|l}
$\mathrm{Au}$ NRs@ $\mathrm{rGO}-$ \\
$\mathrm{COOH}$
\end{tabular} & $\begin{array}{l}\mathrm{Au} \\
\mathrm{NRs} @ \mathrm{rGO}- \\
\mathrm{PEG}\end{array}$ & $\begin{array}{l}\text { Aur NRs@rGO- } \\
\text { PEG-Cy7 }\end{array}$ & \begin{tabular}{|lr}
$\mathrm{Au}$ & NRs@rGO- \\
PEG-Tat/Cy7
\end{tabular} \\
\hline$\zeta / \mathrm{mV}$ & \begin{tabular}{|l|}
$+40 \pm$ \\
2
\end{tabular} & $-45 \pm 2$ & \begin{tabular}{|l|}
$-35 \pm 2$ \\
\end{tabular} & $-16 \pm 2$ & $-10 \pm 2$ & $+15 \pm 2$ \\
\hline
\end{tabular}

The XPS survey spectrum of Au NRs@ $@$ GO-COOH displays bands due to $\mathrm{C}_{1 \mathrm{~s}}(66.8$ at $\%), \mathrm{O}_{1 \mathrm{~s}}$ (30.9 at\%) and $\mathrm{Au}_{4 \mathrm{f}}(2.3 \mathrm{at} \%)$, in accordance with its chemical composition (Fig. 2A). The $\mathrm{C}_{1 \mathrm{~s}}$ high resolution XPS spectrum (Fig. 2B) shows four bands, at $284.5 \mathrm{eV}$ ( $\mathrm{sp}^{2}$ network), $286.5 \mathrm{eV}$ $(\mathrm{C}-\mathrm{O}), 287.9 \mathrm{eV}(\mathrm{CO})$ and $291.3 \mathrm{eV}$ attributed to carbon species of higher oxidation states such as carboxylic acid. The $\mathrm{Au}_{4 \mathrm{f}}$ high resolution XPS spectrum displays two peaks due to $4 \mathrm{f}_{7 / 2}$ and $4 \mathrm{f}_{5 / 2}$ at 84.0 and $87.6 \mathrm{eV}$, respectively (Fig. 2C). The binding energies recorded are consistent with zerovalent Au. $\frac{33}{}$ Raman analysis of Au NRs@ $\mathrm{rGO}-\mathrm{COOH}$ shows a band at $\approx 1590 \mathrm{~cm}^{-1}$, being close to that of pristine graphite, suggesting reduction of GO to $\mathrm{rGO}$ in the process (Fig. 2D). The existence of a D band at $\approx 1362 \mathrm{~cm}^{-1}$ indicates the existence of defects in the in-plane $\mathrm{sp}^{2}$ domain of the samples. The intensity ratio $\left(\mathrm{I}_{\mathrm{D}} / \mathrm{I}_{\mathrm{G}}\right)$ of 0.69 confirms the partial reduction of GO to rGO. $\underline{35}$ The $2 \mathrm{D}$ band located at $2694 \mathrm{~cm}^{-1}$ with an additional shoulder towards higher wavelength suggests in addition a predominant multilayered structure. $\frac{36,37}{}$ The colloidal stability of Au NRs@ rGO-COOH particles in PBS (pH 7.4) was however limited probably due to the hydrophobicity of $\mathrm{rGO}^{38}$ and the nanostructures sedimented after some days at room temperature (Fig. 2E)

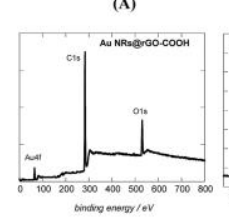

(D)

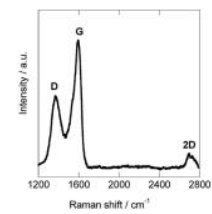

(G)

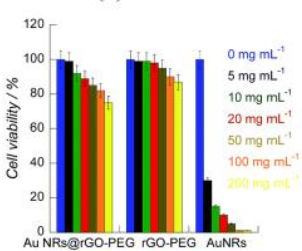

Fig. 2
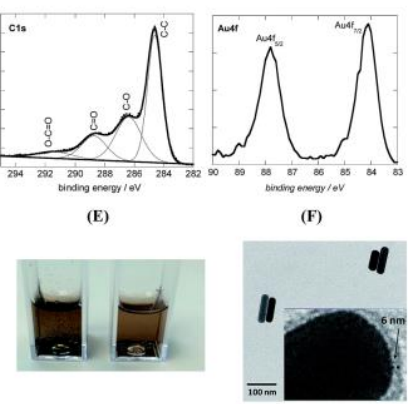

(H)

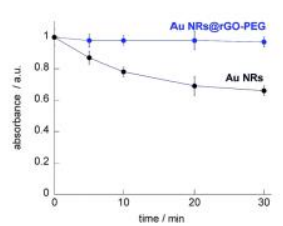

(A) XPS survey spectrum of Au NRs@rGO-COOH, (B) C1s, and (C) Au4f high resolution spectra of Au NRs@ rGO-COOH; (D) Raman spectrum of $\mathrm{Au}$ NRs@rGO-COOH; (E) dispersibility in PBS of Au NRs@rGO-COOH (left) and Au NRs@rGO-PEG (right); (F) TEM image of Au NRs@rGO-PEG; (G) cell viability of U87MG glioblastoma cells upon incubation with different 
concentrations of $\mathrm{Au}$ NRs, rGO-PEG and Au NRs@rGO-PEG; (H) photostability of $\mathrm{Au}$ NRs (black) and Au NRs@rGO-PEG (blue) solution upon irradiation at $808 \mathrm{~nm}(\mathrm{CW}, 1 \mathrm{~W} \mathrm{~cm}-2)$.

To increase the dispersibility of Au NRs@rGO-COOH, amino-terminated PEG $\left(\mathrm{NH}_{2}-\mathrm{PEG}-\right.$ $\mathrm{NH}_{2}$ ) units were covalently conjugated to the carboxylic acid groups of $\mathrm{rGO}-\mathrm{COOH}$ through amide bond formation. ${ }^{33,39-43}$ Upon conjugation the resulting Au NRs@ rGO-PEG exhibited higher solubility and stability in PBS (Fig. 2E), critical for biological applications. An aqueous solution of Au NRs@rGO-PEG was stable for over 2 months at $4{ }^{\circ} \mathrm{C}$ without any apparent aggregation. The TEM image of Au NRs@ rGO-PEG (Fig. 2F) shows the presence of a $\approx 6 \mathrm{~nm}$ coating around the particles.

In this study, we selected human glioblastoma astrocytoma (U87MG) cells as our experimental template. Cell viability experiments were conducted by incubating the cancer cells with $\mathrm{Au}$ NRs@rGO-PEG in the dark for $48 \mathrm{~h}$. As seen in Fig. 2G, the nanomaterial displays good biocompatibility evaluated via MTS assays up to a particle concentration of $100 \mu \mathrm{g} \mathrm{mL}^{-1}$.

One problem using Au NRs for PTT is their instability/melting under NIR resulting in decreased absorbance after a certain period of laser irradiation. ${ }^{44,45} \mathrm{We}$ found that in contrast to Au NRs, $\mathrm{Au}$ NRs@rGO-PEG appeared to be extremely stable under continuous $808 \mathrm{~nm}$ irradiation without any noticeable change in absorbance (Fig. 2H).

Photothermal properties of Au NRs@rGO-PEG and photothermal killing of U87MG cells in vitro

Owing to the strong absorption of Au NRs@rGO-PEG in the NIR region, the photothermal efficiency of the nanostructures was examined and compared to Au NRs and rGO-PEG. Fig. $\underline{3 \mathrm{~A}}$ compares the extent of the temperature rise of water in the presence of the different nanostructures. Upon irradiation using $808 \mathrm{~nm}$ NIR laser at a power density of $0.5 \mathrm{~W} \mathrm{~cm}^{-2}$ the solution temperature increased to $\approx 60{ }^{\circ} \mathrm{C}$ within $10 \mathrm{~min}$ in the presence of Au NRs@rGO-PEG $\left(20 \mu \mathrm{g} \mathrm{m}^{-1}\right)$. The temperature curves of rGO-PEG and Au NRs at equal concentrations exhibited a similar trend, but with less temperature elevation. In contrast, direct irradiation of water showed no apparent increase upon laser irradiation. rGO conjugate to Au NRs brings a synergistic effect and enhances the overall temperature elevation in accordance with previous findings. ${ }^{31,33}$ As expected, the temperature rise of $\mathrm{Au}$ NRs@ $\mathrm{rGO}-\mathrm{PEG}$ solutions is concentration dependent and can be tuned at will upon using the appropriate concentration

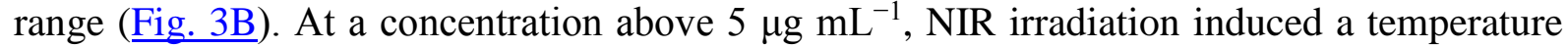
increase up to $\approx 40{ }^{\circ} \mathrm{C}$, which is considered to be high enough for photothermal ablation of cancer cells. ${ }^{46}$ 
(A)

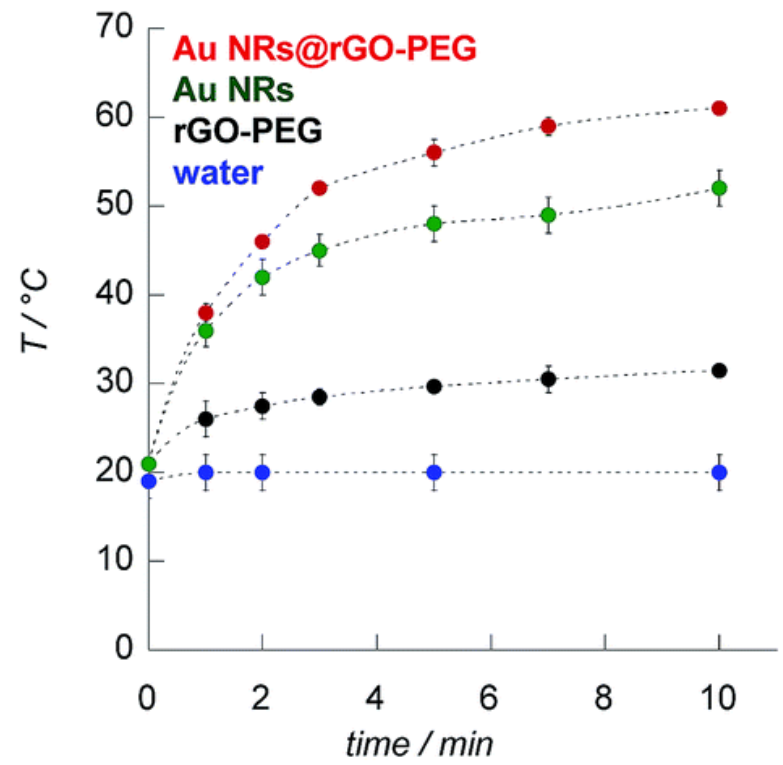

(B)

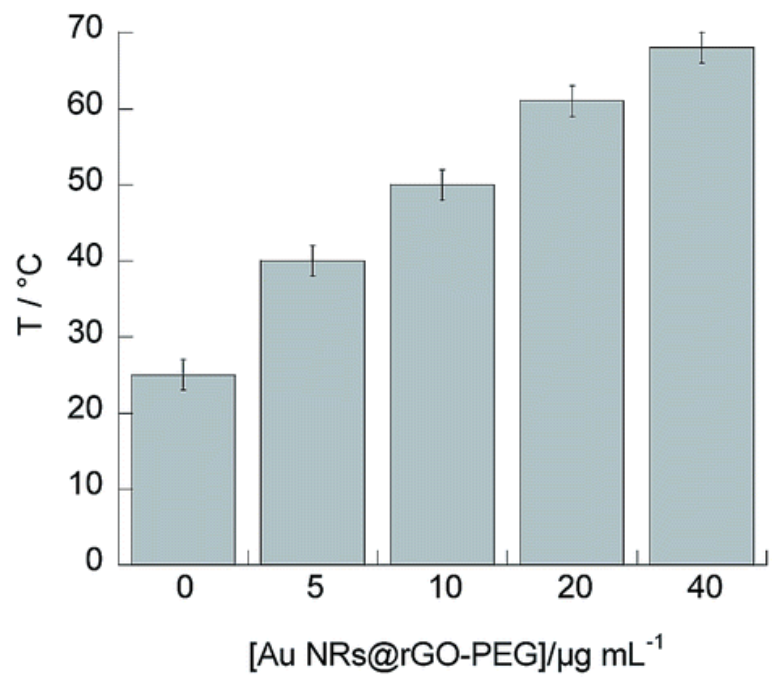

Fig. 3

(A) Photothermal heating curves of different nanostructures dissolved in distilled water $\left(20 \mu \mathrm{g} \mathrm{mL}^{-1}\right)$ under NIR illumination $(800 \mathrm{~nm})$ at $0.5 \mathrm{~W} \mathrm{~cm}^{-2}$ for 10 min using a CW laser: water (blue), rGO-PEG (black), Au NRs (green), $\mathrm{Au}$ NRs@rGO-PEG (red); (B) change in temperature as a function of $\mathrm{Au}$ NRs@rGO-PEG concentration during illumination at $808 \mathrm{~nm}$ for $10 \mathrm{~min}$ at $0.5 \mathrm{~W} \mathrm{~cm}^{-2}$.

To further investigate the ability of Au NRs@rGO-PEG for cancer therapy, the photothermal ablation of human glioblastoma astrocytoma (U87MG) cells was conducted. For specific targeting, Tat peptide, known for its targeting ability towards U87MG cells through terminal arginine bearing a positive charge, was conjugated to the nanomaterials to promote nanomaterial targeting towards the cell. ${ }^{47}$ Tat conjugation was achieved via amide bond formation as observed for other proteins. ${ }^{48-50}$ The amount of Tat protein integrated was determined by UV-Vis spectroscopy to be $20 \mu \mathrm{g}$ per $100 \mu \mathrm{g} \mathrm{mL} \mathrm{m}^{-1}$ of Au NRs@ rGO-PEG (see ESI Fig. S1 $)$. The change to a positive zeta potential (Table 1) from $-10 \pm 2$ to $+15 \pm 2 \mathrm{mV}$ indicates in addition the success of the Tat protein integration.

The photodestruction of U87MG treated with Au NRs@rGO-PEG-Tat and Au NRs@ rGO-PEG was performed using a continuous wave laser at $808 \mathrm{~nm}$ for $10 \mathrm{~min}$ at a laser power of $1 \mathrm{~W}$ $\mathrm{cm}^{-2}$ (Fig. 4A). The cells were incubated for $4 \mathrm{~h}$, washed, irradiated further incubated for $48 \mathrm{~h}$ and a colorimetric MTS metabolic activity assays performed thereafter to determine the overall cell viability. In the absence of irradiation, U87MG cells exposed to Au NRs@ rGO-PEG-Tat showed no significant cytotoxicity, irrespective of the concentration used. Incubation with $\mathrm{Au}$

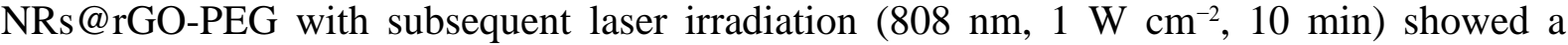
concentration dependent decrease of cell viability (Fig. 4A), with nearly all cells $(\approx 97 \%)$ destroyed after NIR irradiation $\left(\mathrm{EC}_{50}=32 \mu \mathrm{g} \mathrm{mL} \mathrm{mL}^{-1}\right)$. Using Tat-functionalized Au NRs@ $\mathrm{rGO}$ PEG, a lower $\mathrm{EC}_{50}$ was achieved $\left(11 \mu \mathrm{g} \mathrm{mL}^{-1}\right)$, confirming beneficial effect of integrated Tat vectors. Such conditions are comparable to those reported by Akhavan and Ghaderi for the ablation of human glioblastoma cancer cells using graphene nanomesh solutions of $10 \mu \mathrm{g} \mathrm{mL}^{-1}$ with NIR power density of $0.1 \mathrm{~W} \mathrm{~cm}^{-2}$ for 7 min. $^{51}$ 
(A)

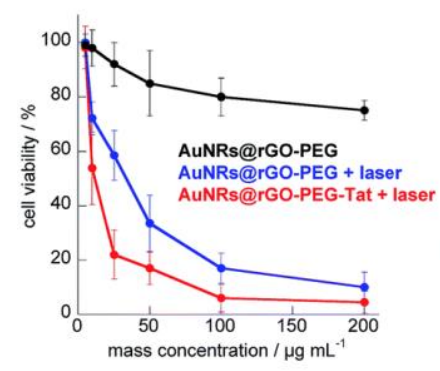

Au NRs@rGO-PEG-FITC
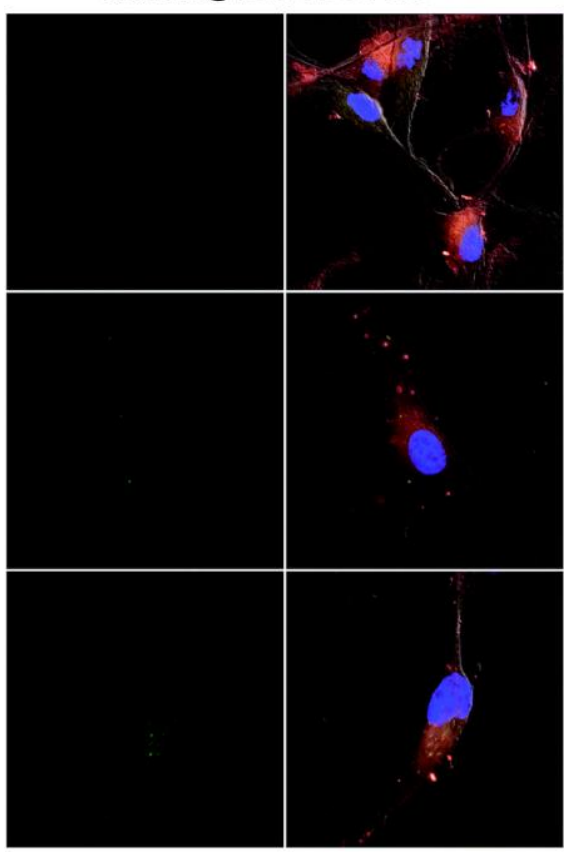

FITC

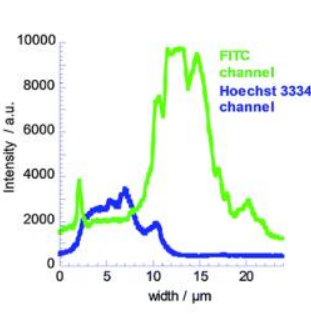

(C)
(B)
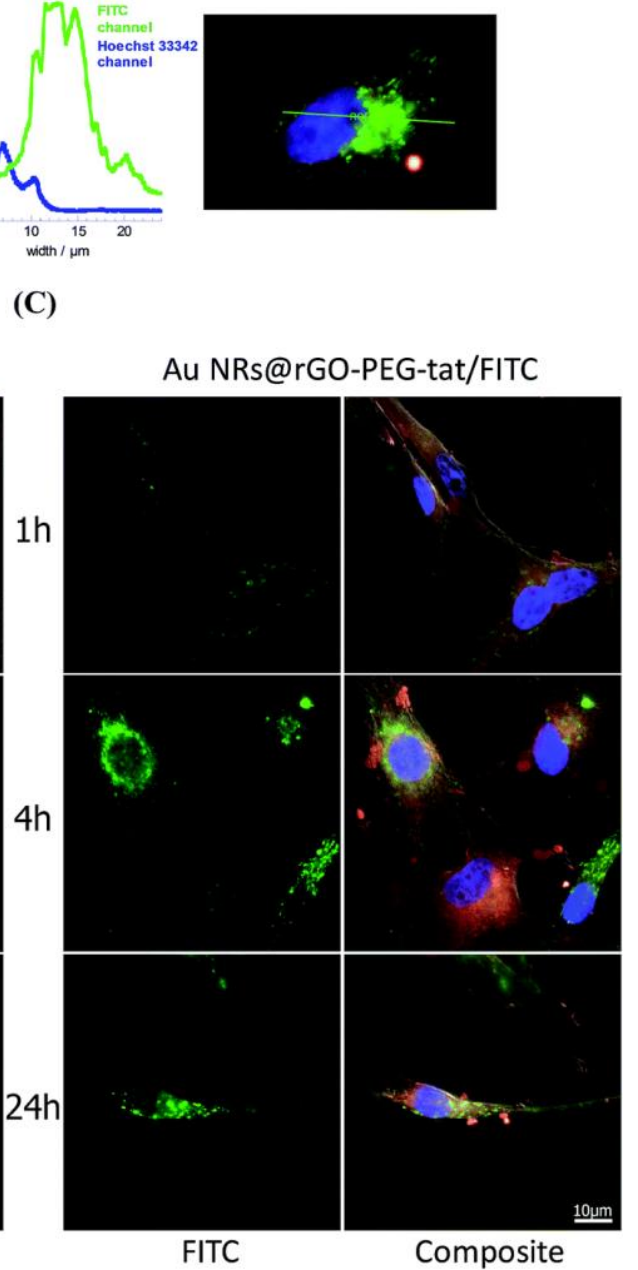

Fig. 4

Cellular localization of functionalized Au NRs. (A) Photothermal U87MG cell killing with Au NRs@ rGO-PEG-Tat and Au NRs@rGO-PEG (detected by MTS assay, data are normalized to untreated cells) of U87MG cells as a function of nanomaterials concentration upon NIR illumination $(\mathrm{CW}, 808$ $\mathrm{nm}$ ) at $1 \mathrm{~W} \mathrm{~cm}^{-2}$ for $10 \mathrm{~min}$; (B) fluorescence intensity profile from $\mathrm{Au}$ NRs@rGO-PEG-Tat/FITC along the indicated line across single U87MG cell. FITC fluorescence is present in the cell surface (small peaks corresponding to cell margins) and in the perinuclear region (center) but absent in the nucleus (counterstained by Hoechst 33342). (C) Fluorescence microscopy images of U87MG cells incubated with Au NRs@rGOPEG/FITC and Au NRs@rGO-PEG-Tat/FITC for 1, 4 and 24 h. Merged images show Hoechst 33342 (blue), CellMask (red) and FITC (green). All images were acquired and represented in the exact same condition to ease visual comparison of fluorescently labeled nanoparticle's uptake.

Internalization of Au NRs@rGO-PEG-Tat into U87MG cells with high efficiency is highly essential in photothermal therapy. To confirm the uptake of the nanostructures, a fluorescent dye (FITC) was further linked to Au NRs@ $@$ rGO-PEG-Tat. ${ }^{52}$ After the cells were incubated with $50 \mu \mathrm{g} \mathrm{mL} \mathrm{mL}^{-1}$ Au NRs@ rGO-PEG-Tat/FITC for 1, 4 and $24 \mathrm{~h}$, confocal microscopic images were acquired and represented in the exact same conditions for ease visual comparison of 
fluorescently labeled nanoparticles' uptake (Fig. 4C). The fluorescence intensity is significantly increased from 1 to $4 \mathrm{~h}$ with a slight drop at $24 \mathrm{~h}$. At $4 \mathrm{~h}$ the highest distribution of $\mathrm{Au}$ NRs@rGO-PEG-Tat/FITC was observed throughout the entire cytoplasm. At the same time non-vectorized nanomaterial showed much weaker signal. These studies suggested that the physico-chemical parameters of Au NRs@rGO-PEG-Tat/FITC strongly influence the nanoparticles' uptake by U87MG cells. Detailed analysis showed the highest fluorescence signal in the perinuclear region presumably some cisternaes of Golgi complex, suggesting an endosome-related pathway of nanoparticles engulfment with subsequent endosome recycling in Golgi ( 10000 a.u.) (Fig. 4B). The edges of the membrane were also saturated with the nanomaterial ( $\sim 4000$ a.u.), visualized by two peaks of fluorescence on cell borders. The high accumulation of the photothermal agent in tumor cells is important and will enable efficient selective photothermal heating.

\section{NIR fluorescence imaging and biodistribution}

To enable in vivo tracking of the Au NRs@rGO-PEG-Tat nanohybrids, labeling with commercially available Cy7-NHS, a commonly used NIR dye, was performed (Fig. 1). Analyzing the supernatant after the covalent coupling reaction by absorption spectra $(750 \mathrm{~nm}$, $199000 \mathrm{~L} \mathrm{~mol}^{-1} \mathrm{~cm}^{-1}$ ) revealed that $10 \mu \mathrm{g} \mathrm{mL}^{-1}$ of $\mathrm{Cy} 7$ was integrated onto $100 \mu \mathrm{g} \mathrm{mL}^{-1} \mathrm{Au}$ NRs@rGO-PEG-Tat.

As a proof-of-concept study, we performed in vivo mice experiments to evaluate the efficacy of the nanostructures. For this, Swiss nude mice with implanted U87MG glioblastoma cells (5 $\times 10^{6}$ cell per mouse) at the right flank were treated with Au NRs@ @GO-PEG-Tat/Cy7 at a dose of $150 \mu \mathrm{L}$ of $1 \mathrm{mg} \mathrm{mL}^{-1}$ per mouse $\left(5 \mathrm{mg} \mathrm{kg}^{-1}\right)$ through intravenous injection into the tail vein (Fig. 5A). The tumor cells were inoculated in Matrigel ${ }^{\mathrm{TM}}$, a polymer matrix which gets polymerized once injected into the living body providing vital components to enable fast tumor growth. ${ }^{53}$ In this case, 18 days were needed to achieve a tumor (spheric shape) of $\sim 500 \mathrm{~mm}^{3}$ in volume (Fig. 6C), estimated to be optimal for the treatment. 


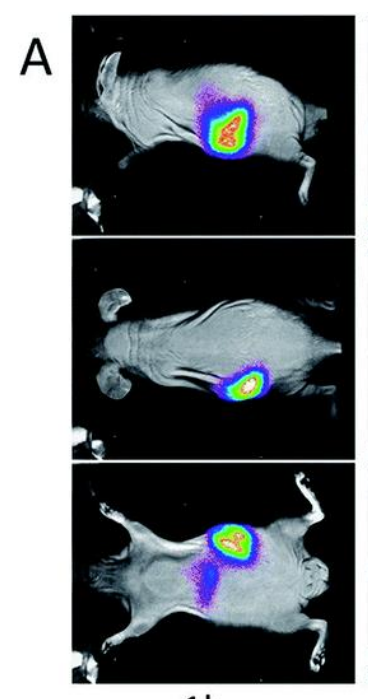

$1 \mathrm{~h}$

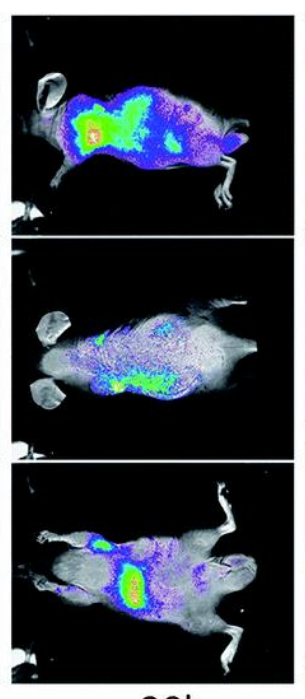

$20 \mathrm{~h}$

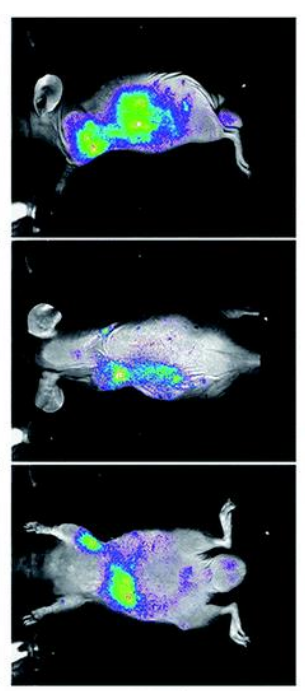

$48 \mathrm{~h}$

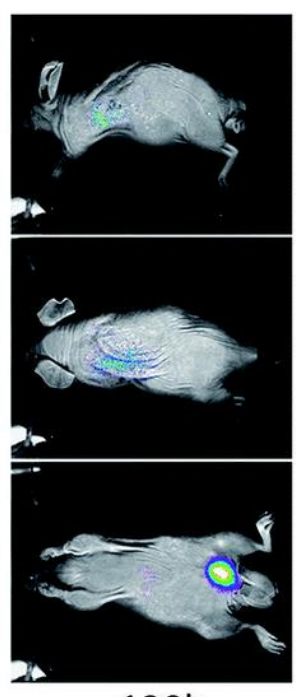

$120 \mathrm{~h}$

B
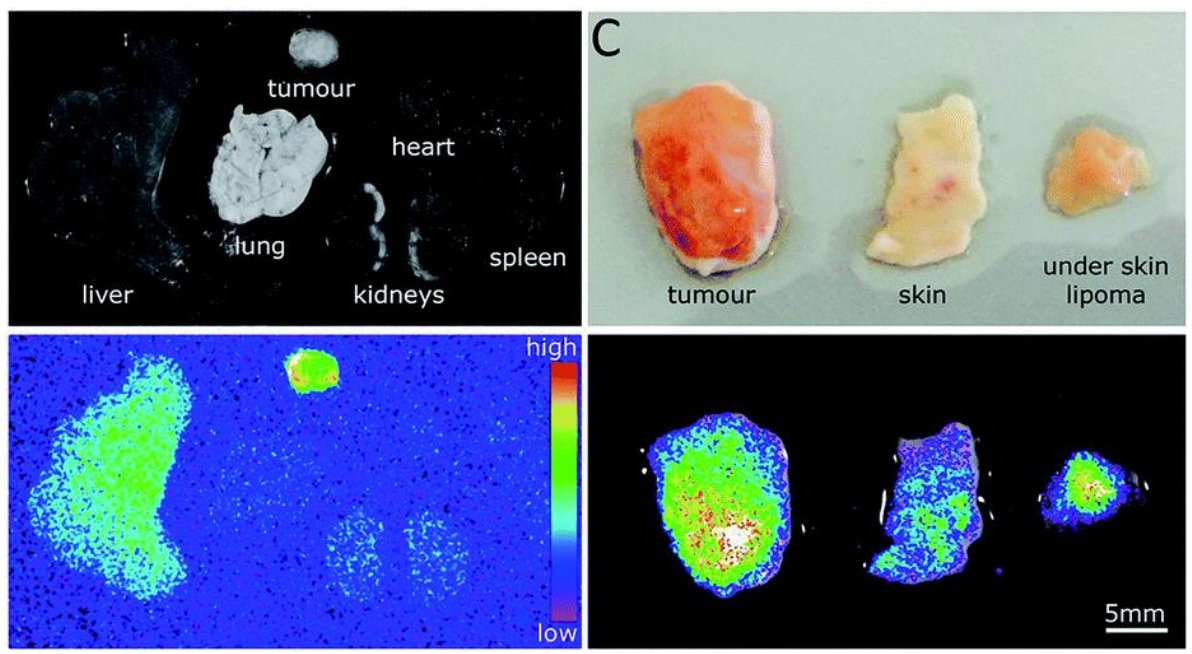

Fig. 5

Biodistribution analysis of Au NRs@rGO-PEG-Tat/Cy7 nanoparticles. (A) In vivo NIR fluorescence images (Cy7) demonstrating distribution in the body of intravenously injected Au NRs@rGO-PEG-Tat/Cy7 nanoparticles after 1, 20, 48 and $120 \mathrm{~h}$ of injection. (B) Accumulation of Au NRs@rGOPEG-Tat/Cy7 in different organs $24 \mathrm{~h}$ after intravenous injection into the tail vein. (C) Distribution of Au NRs@rGO-PEG-Tat/Cy7 in solid tumor, surrounding lipoma tissue and skin, lipoma was located between skin and solid tumor. Fluorescence images taken $24 \mathrm{~h}$ post-injection. 
(A)

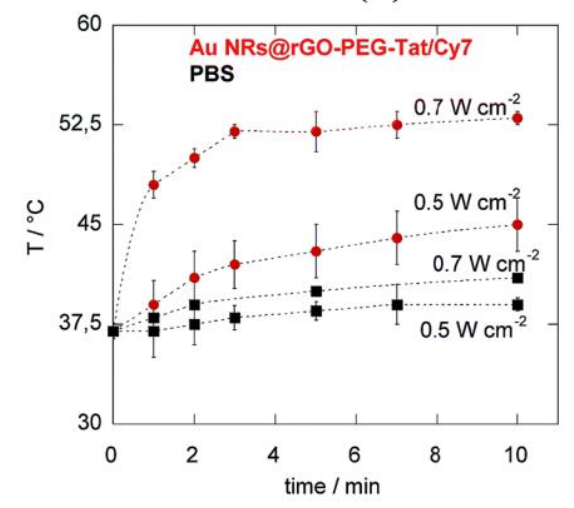

(B)
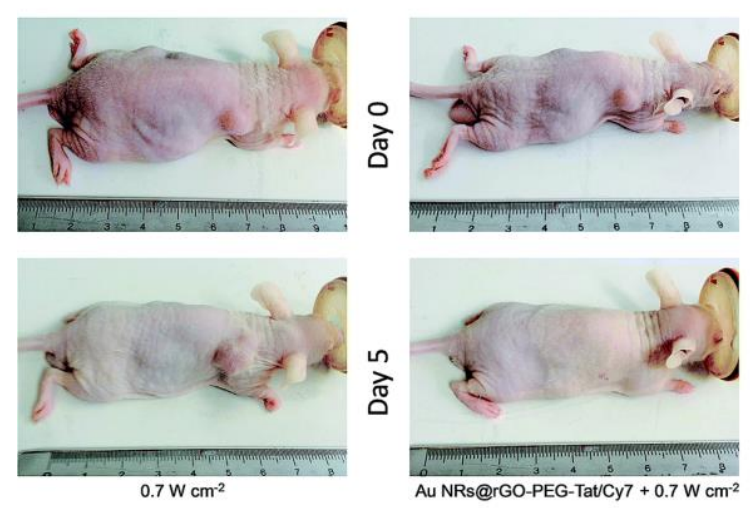

(C)

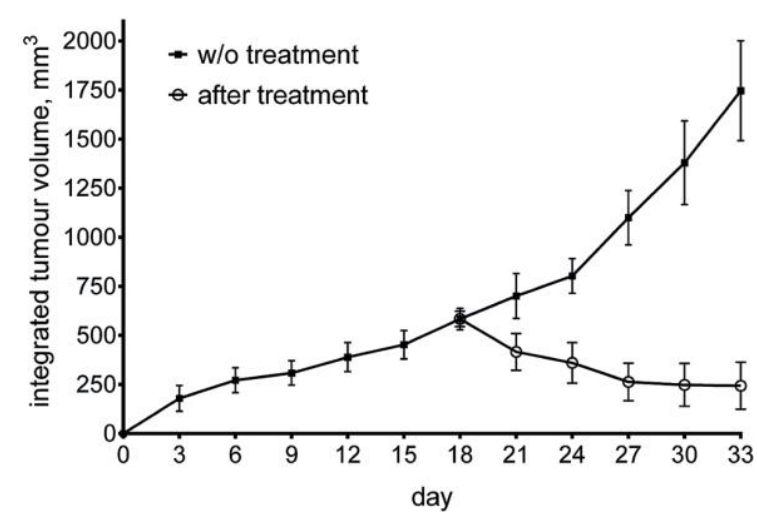

Fig. 6

In vivo photothermal effect of Au NRs@rGO-PEG-Tat/Cy7 in mice. (A) Temperature profiles of the tumor region when exposed to different laser powers $\left(0.5\right.$ and $\left.0.7 \mathrm{~W} \mathrm{~cm}^{-2}\right)$; (B) representative images of mice showing the size of the tumor as indicated by dashed circles at day 0 and 5 after photothermal treatment with and without injected Au NRs@rGOPEG-TatCy7; (C) tumor growth curve in 2 mice groups - with and without photothermal treatment; integrated tumor volume of photothermally treated group significantly decreases 5 days post treatment, while in the untreated group tumor volume dramatically increases with time.

Since the NIR fluorescence can penetrate deep into the tissue of the mouse, the fluorescence signal of Au NRs@rGO-PEG-Tat/Cy7 can be used to locate the particles and whether the nanostructures are vectorized to the tumor. The in vivo NIR fluorescence images ( $\mathrm{Cy} 7$ channel) 
from Au NRs@rGO-PEG-Tat/Cy7 treated mice after 1, 20, 48 and 120 h after intravenous injection are depicted in Fig. 5A. It can be seen, that the nanostructures mainly accumulate in the liver, spleen and right kidney at the initial $1 \mathrm{~h}$, indicating that some of the Au NRs@ rGOPEG-Tat/Cy7 structures are rapidly recognized by the phagocytic cells and the reticuloendothelial system (RES). With the time progressing ( $20 \mathrm{~h}$ post-injection), the signal in the liver and spleen decreases significantly, becoming hardly detectable. In contrast, the fluorescent signal of the nanostructures in the tumor region became stronger, reaching a maximum after $20 \mathrm{~h}$ post-injection. Thereafter, the signal intensity also decays with time with less intensity at $48 \mathrm{~h}$ post-injection. At $24 \mathrm{~h}$ post injection, mice were euthanized and major organs were analyzed for ex vivo fluorescence (Fig. 5B). Obtained data confirmed the highest localization of fluorescence signal in the tumor when compared to other organs, i.e. liver and kidney. The part of skin and lipoma tissue located between tumor and skin were also analyzed demonstrating the highest signal in tumor tissue ex vivo, confirming the targeted localization of the nanomaterials (Fig. 5C). It is apparent, that the strongest NIR fluorescence signal comes from the tumor tissues due to the long blood circulation time and enhanced permeability and retention effect (EPR). $\stackrel{54}{4}$ Analysis of feces showed fluorescence signal, indicating that nanomaterial was cleared from the body through bladder and intestine.

\section{In vivo photothermal treatment of mice with implanted U87MG tumor cells}

To assess the therapeutic effect of Au NRs@ rGO-PEG-Tat/Cy7 on the photothermal treatment of solid tumors, an in vivo antitumor study was performed using U87MG tumor bearing mice as animal model. After intravenous injection into tail vein of $150 \mu \mathrm{g}$ of Au NRs@rGO-PEGTat/Cy7 per mice and accumulation for $20 \mathrm{~h}$ of the nanostructures in the tumor, all mice were subjected to NIR laser irradiation in accordance with all the ethical and safety rules demanded using a portable CW laser with $808 \mathrm{~nm}$ excitation, where the optical fiber was placed $6 \mathrm{~cm}$ above the tumor. Several laser power intensities were tested to optimize the treatment. As $2 \mathrm{~W}$ $\mathrm{cm}^{-2}$ caused severe skin burn, the experiment was performed using a laser power of $0.7 \mathrm{~W} \mathrm{~cm}^{-2}$ to maintain the temperature at $50-52{ }^{\circ} \mathrm{C}$ in the tumor (Fig. 6A), which was shown to be not causing skin burns (Fig. 6B). In contrast, mice without injected nanostructures showed a temperature rise of only $\sim 3{ }^{\circ} \mathrm{C}$ on the tumor region.

The tumor size was measured at the first day of post-treatment and further every 3 days. A significant drop in size was already observed at the $3^{\text {rd }}$ post-treatment day (Fig. 6C) and a tumor size of less than $\sim 100 \mathrm{~mm}^{3}$ was obtained at the 5 day post-treatment. In contrast to this, in the control group, tumors were steadily growing until reaching 10 percent of initial body weight when the mice have been sacrificed according to ethical guidelines. Histological analysis of tumor tissue taken from Au NRs@rGO-PEG-Tat treated mice $3 \mathrm{~h}$ post laser irradiation indicated accumulation of Au NRs nanoparticles in tumor stroma (Fig. 7A-D) and walls of vessels (Fig. 7E-H). Histology revealed active uptake of Au NRs@ rGO-PEG-Tat particles by tumor stroma cells in some tumor areas (ig. 7B). The Au NRs@ rGO-PEG-Tat particles were visualized as black particles by $H \& E$ staining and as strongly absorbing substance using illumination with 620-650 nm red light. The tumor tissue was filled with blood released from capillaries and probably small vessels. The walls of capillaries were not detected, however those few medium-sized vessels which were preserved (Fig. 7H) exhibited intense accumulation of Au NRs@rGO-PEG-Tat in their walls. Selective damages of vessels and anti-angiogenic effect of created Au NRs@rGO-PEG-Tat makes them a very promising effective anti-tumor agent. 


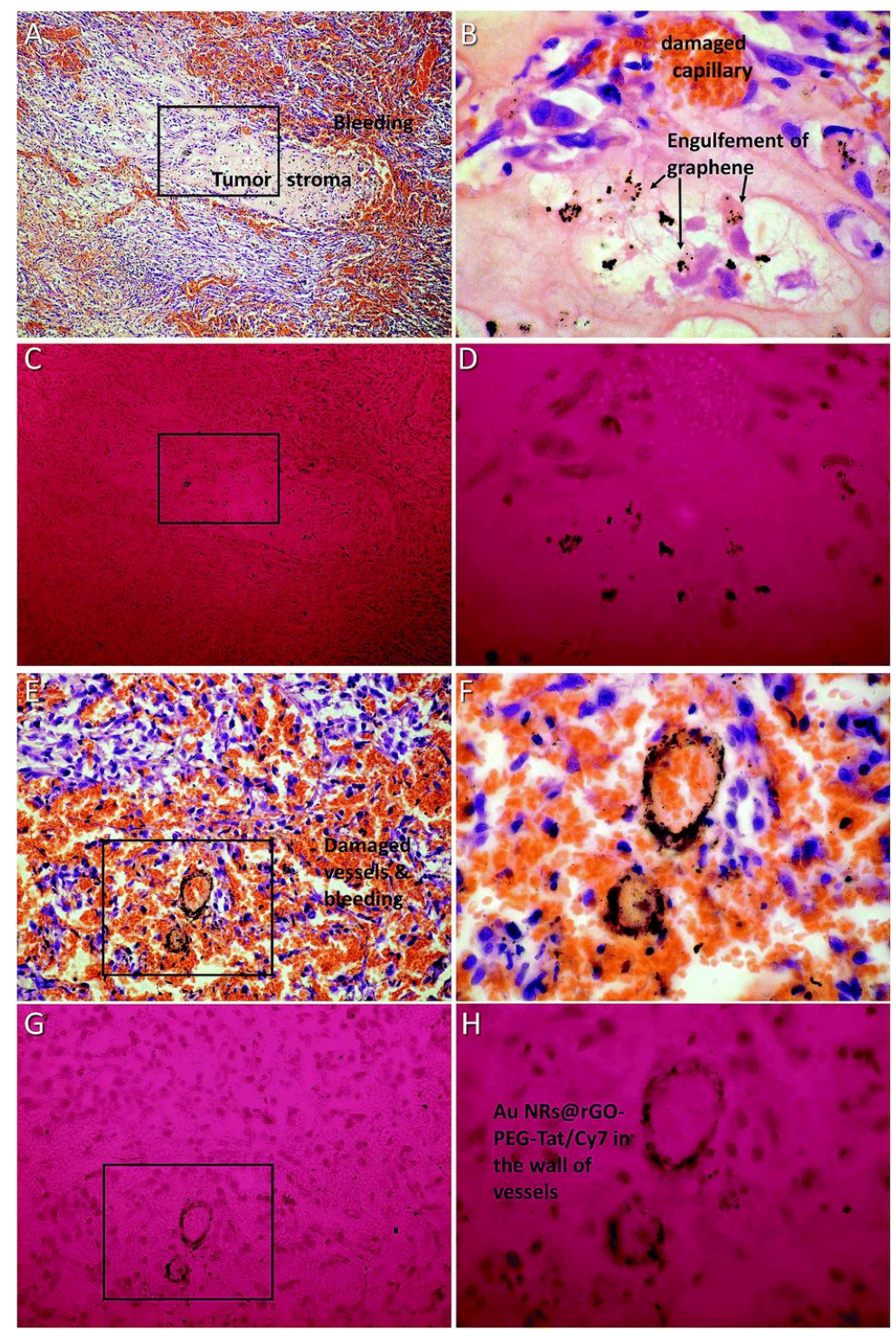

Fig. 7

Histological analysis of tumor tissue obtained $3 \mathrm{~h}$ after photothermal treatment. (A-D) - region of tumor revealing tumor stroma. (B) - is enlarged (100x objective) area of $\mathrm{A}(10 \times$ objective), indicated by rectangle. $(\mathrm{E}-\mathrm{H})$ Region of tumor demonstrating accumulation of Au NRs@rGO-PEGTat/Cy7 in the walls of blood vessels. Please note the massive bleeding resulting from massive vessel damage. $(\mathrm{F})$ is enlarged (40× objective) area of E (10× objective), indicated by rectangle. $(\mathrm{C} \& \mathrm{D}),(\mathrm{G} \& \mathrm{H})$ corresponds to images (A \& B), (E \& F), obtained under red $(620-650 \mathrm{~nm})$ illumination with the aim to visualize Au NRs.

\section{Conclusion}

In summary, we have shown the interest of gold nanorods coated with PEGylated reduced graphene oxide and further modified with tumor vectors and fluorescent dyes for photothermal heating applications. This multifunctional theranostic nanostructures exerted efficient photothermal destruction of tumors in mice upon low dose of NIR light excitation. Due to the specific interaction between tat proteins with human glioblastoma astrocytome (U87MG) cells, selective targeting of the tumor was achieved. Furthermore, the nanostructures can act as fluorescent cellular markers due to the presence of NIR fluorescent dyes integrate onto the rGO 
shell. High accumulation of Au NRs@rGO-PEG-Tat in the tumor was observed, important for efficient and selective photothermal treatment. An endosomal-related uptake with subsequent endosomal recycling in the Golgi complex is suggested. The therapeutic effect of the novel photothermal agent was assessed by in vivo studies performed on tumor bearing mice. It could be shown that a significant drop in tumor size was observed after 5 days, when irradiation the tumor zone at $0.7 \mathrm{~W} \mathrm{~cm}^{-2}$ for $10 \mathrm{~min}$. Histological analysis of tumor tissue revealed in parallel active uptake of the nanoparticles by the tumor stroma cells and selective damage of tumor vessels. This selective damage and anti-angiogenic effect make Au NRs@rGO-PEG-Tat a highly promising anti-tumor agent.

\section{Acknowledgements}

We kindly thank Dr Charles-Henri Hage for his support and helpful discussion on laser set-up. We also kindly thank Dr Vyacheslav Lehen'kiy for providing a support on in vivo protocols and Dr Corentin Spriet for helping in acquiring and analyzing of uptake data. K. T., R. B. , J. B. and S. S. gratefully acknowledge financial support from the Centre National de la Recherche Scientifique (CNRS), Lille University and the Nord Pas-de-Calais region. S. S thanks the Institut Universitaire de France (IUF) for financial support. Supports from the European Union through FP7-PEOPLE-IRSES (No. 269009) and H2020-MSCE-RISE-2015 (PANG, No. 690836) are also acknowledged. We are indebted to the Research Federation FRABio (Univ. Lille, CNRS, FR 3688, FRABio, Biochimie Structurale et Fonctionnelle des Assemblages Biomoléculaires) for providing the scientific and technical environment to conduct this work.

\section{References}

1. S.-E. Jin, H.-E. Jin and S.-S. Hong, BioMed Res. Int., 2014, ID814208

2. Y.-E. L. Koo, G. R. Reddy, M. Bhojani, R. Schneider, M. A. Philbert, A. Rehemtulla, B. D. Ross and R. Kopelman, Adv. Drug Delivery Rev., 2006, 58, 1556-1577

3. S. Nazir, T. Hussain, A. Ayub, U. Rashid and A. J. MacRobert, Nanomedicine, 2014, $10,19-34$

4. J. Wang, T. T. Wang, P. F. Gao and C. Z. Huang, J. Mater. Chem. B, 2014, 2, 84528465

5. G. Baffou and R. Quidant, Laser Photonics Rev., 2011, 7, 171-187

6. X.-M. Zhu, C. Fang, H. Jia, Y. Huang, C. H. K. Cheng, C.-H. Ko, Z. Chen, J. Wang and Y.-W. J. Wang, Nanoscale, 2014, 6, 11462-11472

7. R. Vankayala, C.-C. Lin, P. Kalluru, C.-S. Chiang and K. C. Hwang, Biomaterials, 2014, 35, 5527-5538

8. W.-S. Kuo, C.-N. Chang, Y.-T. Chang, M.-H. Yang, Y.-H. Chien, S.-J. Chen and C.-S. Yeh, Angew. Chem., Int. Ed., 2010, 122, 2771-2775.

9. E. D. Dreaden, A. M. Alkilany, X. Huang, C. J. Murphy and M. A. El-Sayed, Chem. Soc. Rev., 2012, 41, 2740-2779.

10. P. C. Naha, P. Chhour and D. P. Cormode, Toxicol. In Vitro, 2015, 29, 1445-1453.

11. P. Chhour, P. C. Naha, R. Cheheltani, B. Benardo, S. Mian and D. P. Cormode, Nanomaterials in Pharmacology, ed. Zheng-Rong Lu and Shinji Sakuma, Publisher: Springer, New York, 2016, ch. 5, pp.87-111.

12. S. Szunerits and R. Boukherroub, Chem. Commun., 2012, 48, 8999-9010.

13. V. P. Zharov, K. E. Mercer, E. N. Galitocskaya and M. S. Schmeltzer, Biophys. J., 2006, 90, 619.

14. R. S. Norman, J. W. Stone, A. Gole, C. J. Murphy and T. L. Sabo-Attwood, Nano Lett., 2008, 8, 302.

15. W.-C. Huang, P.-J. Tsa and Y.-C. Che, Nanomedicine, 2007, 2, 777. 
16. S. A. Khan, A. K. Singh, D. Senapati, Z. Fan and P. C. Ray, J. Mater. Chem., 2011, 21, 17705.

17. S. Wang, A. K. Singh, D. Senapati, A. Neely, H. Yu and P. C. Ray, Chem.-Eur. J., 2010, 16, 5600.

18. H. Chen, L. Shao, Q. Li and J. Wang, Chem. Soc. Rev., 2013, 42, 2679-2724.

19. M. A. Mackey, M. R. K. Ali, L. A. Austin, R. D. Near and M. A. El-Sayed, J. Phys. Chem. B, 2014, 118, 1319.

20. E. Akhavan and E. Ghaderi, Small, 2013, 9, 3593.

21. H. Kim and W. J. Kim, Small, 2014, 10, 117.

22. X. Huang, P. K. Jain, I. H. El-Sayed and M. A. El-Sayed, J. Laser. Med. Sci., 2008, 23, 217.

23. K. Turcheniuk, R. Boukherroub and S. Szunerits, J. Mater. Chem. B, 2015, 3, 43014324.

24. Y. Ma, X. Liang, S. Tong, G. Bao, D. Ren and Z. Dai, Adv. Funct. Mater., 2013, 23, $815-822$.

25. J. Chen, D. Wang, J. Xi, L. Au, A. Siekkinen, A. Warsen, Z. Y. Li, H. Zhang, Y. Xia and X. Li, Nano Lett., 2007, 7, 1318-1322.

26. W.-S. Kuo, Y.-T. Chang, K.-C. Cho, K.-C. Chiu, C.-H. Lien, C.-S. Yeh and S.-J. Che, Biomaterials, 2012, 33, 3270-3278.

27. Y. Wang, K. C. Black, H. Luehmann, W. Li, Y. Zhang, X. Cai, D. Wan, S.-Y. Liu, M. Li and P. Kim, ACS Nano, 2013, 7, 2068-2077.

28. S.-H. Seo, B.-M. Kim, A. Joe, H.-W. Han, X. Chen and Z. Cheng, Biomaterials, 2014, $35,3309-3318$.

29. Z. Xiao, C. Ji, J. Shi, E. M. Pridgen, J. Frider, J. Wu and O. C. Farokhzad, Angew. Chem., Int. Ed., 2012, 51, 11853-11857.

30. S. A. Khan, R. Kanchanapally, Z. Fan, L. Beqa, A. K. Singh, D. Senapati and P. C. Ray, Chem. Commun., 2012, 48, 6711-6713.

31. D.-K. Lim, A. Barhoumi, R. G. Wylie, G. Reznor, R. S. Langer and D. S. Kohane, Nano Lett., 2013, 13, 4075-4079.

32. C. Xu, L. Yang, L. Mei, Q. Li, H. Zhu and T. T. Wang, ASC Appl. Mater. Interfaces, 2013, 5, 12911-12920.

33. K. Turcheniuk, C.-H. Hage, J. Spadavecchia, A. Y. Serrano, I. Larroulet, A. Pesquera, A. Zurutuza, M. G. Pisfil, L. Heliot, J. Bouckaert, R. Boukherroub and S. Szunerits, J. Mater. Chem. B, 2015, 3, 375-386.

34. K. Turcheniuk, C.-H. Hage, L. Heliot, S. Railyan, V. Zaitsev, J. Spadavecchia, R. Boukherroub and S. Szunerits, Nano LIFE, 2015, 5, 1540002.

35. J. Chen, H. Liu, C. Zhao, G. Qin, G. Xi, T. Li, X. Wang and T. Chen, Biomaterials, 2014, 35, 4986.

36. E. Akhavan and E. Ghaderi, J. Phys. Chem. B, 2011, 115, 9279.

37. K. S. Kim, Y. Zhao, H. Jang, S. Y. Lee, J. M. Kim, K. S. Kim, J.-H. Ahn, P. Kim, J.-Y. Choi and B. H. Hong, Nature, 2009, 457, 706.

38. H. K. Moon, S. H. Lee and H. C. Choi, ACS Nano, 2009, 3, 3707.

39. H. Wen, C. Dong, H. Dong, A. Shen, W. Xia, X. Cai, Y. Song, X. Li, Y. Li and D. Shi, Small, 2012, 5, 760-769.

40. M. Zhao, M. F. Kircher, L. Josephson and R. Weissleder, Bioconjugate Chem., 2002, $13,840-844$.

41. W. Zhang, Z. Guo, D. Huang, Z. Liu, X. Guo and H. Zhong, Biomaterials, 2011, 32, 8555-8591.

42. J. T. Robinson, S. M. Tabakman, Y. Liang, H. Wang, H. S. Casalongue, D. Vinh and H. Dai, J. Am. Chem. Soc., 2011, 133, 6825-6831. 
43. O. Akhhavan, E. Ghaderi and H. Emamy, J. Mater. Chem., 2012, 22, 20626.

44. J. Chen, B. Wiley, Z.-Y. Li, D. Campbell, F. Saeki, H. Cang, L. Au, J. Lee, X. Li and Y. Xia, Adv. Mater., 2005, 17, 2255-2261.

45. S. Link, Z. L. Wang and M. A. El-Sayed, J. Phys. Chem. B, 2000, 104, 7867-7870.

46. H. S. Jung, W. H. Kong, D. K. Sung, M.-Y. Lee, S. E. Beack, D. H. Keum, K. S. Kim, S. H. Yun and S. K. Hahn, ACS Nano, 2014, 8, 260-268.

47. S. P. Lim and A. Garzino-Demo, J. Virol., 2000, 74, 1632-1640.

48. P. Subramanian, A. Lesniewski, I. Kaminska, A. Vlandas, A. Vasilescu, J. NiedziolkaJonsson, E. Pichonat, H. Happy, R. Boukherroub and S. Szunerits, Biosens. Bioelectron., 2013, 50, 239-243.

49. F. Teodorescu, L. Rolland, V. Ramarao, A. Abderrahmani, D. Mandler, R. Boukherroub and S. Szunerits, Chem. Commun., 2015, 51, 14167-14170.

50. X. Q. Wei, L. Y. Hao, X. R. Shao, Q. Zhang, X. Q. Jia, Z. R. Zhang, Y. F. Lin and Q. Peng, ACS Appl. Mater. Interfaces, 2015, 7, 13367-13374.

51. E. Akhavan and E. Ghaderi, Small, 2013, 9, 3593-3601.

52. J. Chen, H. Liu, C. Zhao, G. Qin, G. Xi, T. Li, X. Wang and T. Chen, Biomaterials, 2014, 35, 4986.

53. C. Dubois, F. Vanden Abeele, V. Lehen'kyi, D. Gkika, B. Guarmit, G. Lepage, C. Slomianny, A. S. Borowiec, G. Bidaux, M. Benahmed, Y. Shuba and N. Prevarskaya, Cancer Cell, 2014, 26, 19-32.

54. R. Chen, X. Wang, X. Yao, X. Zheng, J. Wang and X. Jiang, Biomaterials, 2013, 34, $8314-8322$ 